\title{
Seasonal Fluctuation of Yellow Stem Borer Scirpophaga incertulas (walker) on Paddy and its Relationship between Trap Catches with Weather Parameters
}

\author{
D. Pallavi ${ }^{1}$, Sharanabasappa ${ }^{2}$ and P. Megaladevi ${ }^{2}$ \\ ${ }^{1}$ Gkvk, UAS, Bengaluru- 560065, Karnataka, India \\ ${ }^{2}$ Department of Agricultural Entomology, College of Agriculture, UAHS, \\ Shivamogga 577 225, Karnataka, India \\ *Corresponding author
}

\section{A B S T R A C T}

\section{Keywords}

Seasonal

fluctuation, Yellow

stem borer,

Correlation

Article Info

Accepted:

24 August 2018

Available Online:

10 September 2018
In order to understand seasonal incidence, crop loss estimation and management of yellow stem borer Scirpophaga incertulas (walker) on paddy, studies were conducted during 2015 at ZAHRS, College of Agriculture, Shivamogga. The highest incidence of dead heart and white ear was noticed during third week of April and third week of May. Maximum temperature had significant positive correlation whereas minimum temperature, sunshine hours and afternoon relative humidity had non significant positive correlation and in Kharif, the incidence was high during second and third week of September. Maximum temperature had significant positive correlation and minimum temperature, total rainfall, sunshine hours had non significant positive correlation. In pheromone trap, peak moth catches of 44.40 moths was recorded during fourth week of April and there was a significant positive correlation with maximum temperature, sunshine hours and minimum temperature. During Kharif, Peak catches of 35.20 moths was recorded during third week of September. Maximum temperature, sunshine hours exerted positive correlation.

\section{Introduction}

Among several insects that feed on rice, stem borers are considered as the most important, in particular the yellow stem borer Scirpophaga incertulas (Walker) and S. innotata (Walker) (Lepidoptera: Pyralidae). S. incertulas usually comprised more than $90 \%$ of the borer population in rice, and are the common pests in Asian countries and cause 5 to $10 \%$ annual damage (Pathak and Khan, 1994). When heavily infested with more than 5 panicles destroyed, rice hills can have as much as $80 \%$ loss in yield. For developing any pest management programme, specific agroecosystem information on abundance and distribution of pest in relation to weather parameters is a basic requirement (Patel and Shekh, 2006). Therefore, it is necessary to have a thorough knowledge on seasonal incidence and its relation with weather parameters. With this in view, the present study was conducted to assess the peak period of incidence of $S$. incertulas on rice in Shivamogga district. 
Among the semio-chemicals, sex pheromones play a vital role in intra-specific communication, particularly for mating between male and female insects. Recently, sex pheromones have been found promising for management of yellow stem borer. The sex pheromone mediated traps can be used for monitoring yellow stem borer populations as well as direct management. Among the various control measures, most commonly used measure for reducing pest population and sometime the only practical solution to sudden outbreak of insect pests. The development of resistance in insect biotypes to insecticides has to be explored for managing rice pests. The new insecticides could be effective in reducing the pest damage, cost effective, biodegradable, safer to natural enemies and other non targeted organisms

\section{Materials and Methods}

In order to study the incidence of yellow stem borer and to work out their correlation with prevailing weather parameters, an experiment was conducted at ZAHRS, Shivamogga during summer and Kharif seasons of 2015. The rice variety JGL-1798 was sown over an area of $500 \mathrm{sq} \mathrm{m}$ and seedlings were transplanted with a spacing of $20 \times 10 \mathrm{~cm}$ to assess the incidence of yellow stem borer (S. incertulas) in both the seasons on transplanted paddy. All the recommended cultivation practices were followed during the period of investigation except plant protection measures.

The incidence of yellow stem borer infestation was recorded from transplanting to harvesting at weekly interval. The per cent borer incidence was assessed by counting number of dead hearts (DH) in vegetative stage and number of white ear heads (WEH) during reproductive stage from five randomly selected spots each with ten hills. Per cent incidence was calculated using the formula, (Hugar and Hosamani, 2010).
Per cent dead heart $=$

Number of Dead hearts

$\longrightarrow \times 100$

Total number of tillers

Per cent white ear heads $=$

Number of white ear heads x 100

Total number of ear heads

To study the effect of major weather factors viz., maximum and minimum temperature, morning and afternoon relative humidity, rainfall and sunshine hours on incidence of pest in both the seasons, a correlation coefficient was worked out. The weekly per cent dead hearts or white ear heads as dependent variable with weekly mean meteorological data as independent variable was taken. Meteorological data were recorded from the observatory unit situated at College of Agriculture, Shivamogga.

Sex pheromone traps (sleeve trap) for yellow stem borer @ 5 traps in an area of 10 acres was installed during Summer and Kharif season of 2015. Traps were fixed to the supporting pole at a height of one foot above the plant canopy. The traps were installed when crop was transplanted to main field and traps were placed at a distance of $>75$ feet apart. Cotton swab dipped in Diclorvas 76 EC was used inside the polythene bag to kill the moths getting trapped. The number of moths/trap/week was counted a week after transplanting to till harvest of the crop in both the seasons. Lures were replaced once in three weeks. The weather parameters viz., maximum temperature, minimum temperature, relative humidity, rainfall, wind velocity etc. were recorded daily from the meteorological unit, UAHS, Shivamogga. The trap catches were correlated with the weather parameters (Krishnaiah and Varma, 2011). 


\section{Results and Discussion}

During Summer, the incidence of yellow stem borer began in the $11^{\text {th }}$ standard week and it was varied from 4.60 to 46.40 per cent and continued up to $25^{\text {th }}$ standard week. The maximum dead heart was observed during $16^{\text {th }}$ (46.40 per cent) standard meteorological week i.e., third week of April and with a minimum dead heart, later on the incidence declined gradually of 4.60 per cent during second week of March (Table 1).

With respect to per cent white ear, it was started in the reproductive stage of the crop at $18^{\text {th }}$ standard week and continued until $25^{\text {th }}$ standard week and it was varied from 8.00 to 22.00 per cent. The maximum white ear was observed in $20^{\text {th }}$ (22.00 per cent white ear) standard week i.e., third week of May and minimum white ear was observed in $23^{\text {rd }}(8.00$ per cent white ear) standard week i.e., first week of June (Table 1).

From the correlation studies it can be concluded that maximum temperature $(\mathrm{r}=$ $0.489^{*}$ ) had significant positive effect on per cent dead heart where as non significant negative association was observed with morning relative humidity $(\mathrm{r}=-0.52 *)$. On the other hand Minimum temperature $(\mathrm{r}=0.295)$, afternoon relative humidity $(\mathrm{r}=0.369)$ and sunshine hours $(r=0.313)$ had non significant positive correlation where as total rainfall $(\mathrm{r}=$ 327)had a non significant negative influence on per cent dead heart (Table 2).

The correlation studies made between per cent white ear and weather parameters showed that there was a significant positive correlation with Total rainfall $\left(\mathrm{r}=+0.487^{*}\right)$ and afternoon relative humidity $\left(\mathrm{r}=+0.779^{*}\right)$ where as maximum temperature $\left(\mathrm{r}=-0.587^{*}\right)$ and sunshine hours $\left(\mathrm{r}=-0.525^{*}\right)$ exerted negative significant correlation on per cent white ear. On the other hand minimum temperature $(r=$
$0.369)$, morning relative humidity $(\mathrm{r}=0.018)$ showed non significant positive influence on per cent white ear. However, the influence of total rainfall, afternoon relative humidity and maximum temperature was found to be statistically significant (Table 2).

During Kharif The infestation of Scirpophaga incertulas appeared on the host plant varied from 0.40 to 31.20 per cent dead heart and started at $33^{\text {rd }}(0.40$ per cent $)$ standard week and continued up to $47^{\text {th }}$ (4.40 dead heart) standard week The maximum dead heart was observed in $38^{\text {th }}$ (31.20 per cent) standard week i.e., during second week of September and with the minimum of 0.40 per cent was observed in $33^{\text {rd }}$ standard week i.e., during second week of August (Table 1).

The white ear damage was started at $39^{\text {th }}$ (24.00 per cent white ear) standard week continued up to $47^{\text {th }}$ (9.60 per cent) standard week and it was varied from 8.00 to 24.00 per cent. The maximum white ear of 24.00 per cent was observed in $39^{\text {th }}$ standard week i.e., third week of September and minimum of 8.80 per cent was observed in $42^{\text {nd }}$ standard week i.e., third week of October (Table 1).

The results revealed that maximum temperature $\left(r=0.488^{*}\right)$ had a significant positive correlation where as total rainfall $(\mathrm{r}=$ $0.089)$, minimum temperature $(r=0.025)$ and sunshine hours $(r=0.08)$ had non siginificant positive association with per cent dead heart. On the other hand morning relative humidity $(r=-0.013)$ and afternoon relative humidity $(\mathrm{r}=-0.224)$ showed non significant negative correlation. However, the influence of maximum temperature was found to be statistically significant (Table 2).

Correlation studies with respect to per cent white ear revealed that morning relative humidity $\left(\mathrm{r}=-0.557^{*}\right)$ showed a significant negative correlation where as Total rainfall $(\mathrm{r}=$ 
-0.032), minimum temperature $(\mathrm{r}=-0.363)$, after relative humidity $(r=-0.435)$ had a non significant negative influence with the white ear. On the other hand maximum temperature $(r=0.198)$ and sunshine hours $(r=0.064)$, had non significant positive correlation but finally only the influence of morning relative humidity was found to be statistically significant (Table 2).

During summer, the male Scirpophaga incertulas moth trap catches baited with sex pheromone were initiated from $1^{\text {st }}$ week of February with 0.20 moths/week and showed increasing trend up to $20^{\text {th }}$ standard meteorological week (42 moths/week). The Peak trap catches of moth was observed during $17^{\text {th }}$ standard week (44.40 moth trap) However, higher moth catches was recorded between the weeks of $15^{\text {th }}$ to $20^{\text {th }}$ standard week (39.4 to 51moths/week) (Table 3; Fig. 3 and 4).

The results on the correlation studies revealed that maximum temperature $\left(\mathrm{r}=0.51^{*}\right)$, sunshine hours $\left(r=0.411^{*}\right)$ and minimum temperature $\left(\mathrm{r}=0.672^{*}\right)$ had significant positive correlation while morning relative humidity $(\mathrm{r}=-0.562 *)$ shows significant negative influence on moth catches. On the other hand Total rainfall( $\mathrm{r}=-0.096)$, afternoon relative humidity $(r=-0.229)$ exerted non significant negative relationship (Table 4).

In Kharif Population of male yellow stem borer moths captured per week was started from $4^{\text {th }}$ week of July with 0.20 moth/week and showed increasing trends up to $38^{\mathrm{h}}$ meteorological standard week. However, higher moth catches was recorded between the weeks of $35^{\text {th }}$ to $38^{\text {th }}$ standard week (27.40 to 35.20 moths). The highest trap catches of 35.20 moths/week was recorded during $38^{\text {th }}$ meteorological standard week.

The correlation studies made between yellow stem borer catches and weather parameters showed that there was a significant positive correlation with maximum temperature $(\mathrm{r}=$ $0.477)$ where as sunshine hours $\left(\mathrm{r}=-0.55^{*}\right)$ and total rainfall $\left(\mathrm{r}=-0.379^{*}\right)$ showed significant negative influence on moth catches. While minimum temperature $(r=$ 0.364 ) had positive non significant correlation. On the other hand morning relative humidity $(\mathrm{r}=-0.376)$ and afternoon relative humidity $(\mathrm{r}=-0.307)$ exerted non significant negative relationship (Table 4).

Table.2 Correlation matrix between weather parameters and incidence of yellow stem borer during Summer and Kharif2015

\begin{tabular}{|c|c|c|c|c|c|c|c|}
\hline \multirow{3}{*}{ Particulars } & \multirow{3}{*}{$\begin{array}{l}\text { Total } \\
\text { rainfall } \\
\text { (mm) } \\
\text { (X1) }\end{array}$} & \multicolumn{5}{|c|}{ Weather factors } & \multirow{3}{*}{$\mathrm{R}^{2}$} \\
\hline & & \multicolumn{2}{|c|}{ Temperature $\left({ }^{0} \mathrm{C}\right)$} & \multicolumn{2}{|c|}{ Relative humidity (\%) } & \multirow{2}{*}{$\begin{array}{l}\begin{array}{l}\text { Sunshine } \\
\text { (hours/day) }\end{array} \\
\text { (X6) }\end{array}$} & \\
\hline & & $\begin{array}{l}\text { Maximum } \\
\text { (X2) }\end{array}$ & $\begin{array}{l}\text { Minimum } \\
\text { (X3) }\end{array}$ & $\begin{array}{l}\text { I(Morning) } \\
\text { (X4) }\end{array}$ & $\begin{array}{l}\text { II(Afternoon) } \\
\text { (X5) }\end{array}$ & & \\
\hline & \multicolumn{6}{|c|}{ Summer season } & \\
\hline $\begin{array}{l}\text { Dead heart } \\
(\%)\end{array}$ & -0.327 & $+0.489 *$ & +0.295 & $*_{-} 0.52$ & +0.369 & 0.313 & 0.59 \\
\hline \multirow[t]{2}{*}{ White ear(\%) } & $+0.487 *$ & $-0.587 *$ & +0.369 & +0.018 & $+0.779 *$ & $-0.525^{*}$ & 0.75 \\
\hline & \multicolumn{6}{|c|}{ Kharif season } & \\
\hline $\begin{array}{l}\text { Dead heart } \\
(\%)\end{array}$ & +0.089 & $+0.488^{*}$ & +0.025 & -0.013 & -0.224 & +0.08 & 0.39 \\
\hline White ear(\%) & -0.032 & +0.198 & -0.363 & $-0.557 *$ & -0.435 & +0.064 & 0.56 \\
\hline
\end{tabular}

$\mathrm{N}=17 ; *$ significance at $\mathrm{p}=0.05$; Table $\mathrm{r}$ value at $\mathrm{p}=0.05$ is 0.482 
Table.1 Seasonal incidence of yellow stem borer during Summer and Kharif season 2015

\begin{tabular}{|c|c|c|c|c|c|}
\hline Season & Month & SMW & $\begin{array}{l}\text { Crop growth } \\
\text { stages }\end{array}$ & $\begin{array}{l}\text { Dead heart } \\
(\%)\end{array}$ & White ear (\%) \\
\hline \multirow{17}{*}{ Summer } & FEB & 9 & \multirow{7}{*}{$\begin{array}{l}\text { Vegetative } \\
\text { stage }\end{array}$} & 0.00 & 0.00 \\
\hline & MAR & 10 & & 0.00 & 0.00 \\
\hline & & 11 & & 4.60 & 0.00 \\
\hline & & 12 & & 16.80 & 0.00 \\
\hline & & 13 & & 15.60 & 0.00 \\
\hline & APR & 14 & & 26.80 & 0.00 \\
\hline & & 15 & & 43.20 & 0.00 \\
\hline & & 16 & \multirow{4}{*}{$\begin{array}{l}\text { Reproductive } \\
\text { stage }\end{array}$} & 46.40 & 0.00 \\
\hline & & 17 & & 32.00 & 0.00 \\
\hline & MAY & 18 & & 27.20 & 13.33 \\
\hline & & 19 & & 12.80 & 15.34 \\
\hline & & 20 & \multirow{6}{*}{$\begin{array}{l}\text { Ripening } \\
\text { stage }\end{array}$} & 23.20 & 22.00 \\
\hline & & 21 & & 11.20 & 12.66 \\
\hline & & 22 & & 12.00 & 14.66 \\
\hline & JUN & 23 & & 11.60 & 8.00 \\
\hline & & 24 & & 4.98 & 6.95 \\
\hline & & 25 & & 5.10 & 6.00 \\
\hline Mean & & & & 18.15 & 6.09 \\
\hline S.D \pm & & & & 11.03 & 7.17 \\
\hline \multirow{17}{*}{ Kharif } & JULY & 31 & \multirow{7}{*}{$\begin{array}{l}\text { Vegetative } \\
\text { stage }\end{array}$} & 0.00 & 0.00 \\
\hline & AUG & 32 & & 0.00 & 0.00 \\
\hline & & 33 & & 1.40 & 0.00 \\
\hline & & 34 & & 6.00 & 0.00 \\
\hline & & 35 & & 12.00 & 0.00 \\
\hline & & 36 & & 12.40 & 0.00 \\
\hline & SEPT & 37 & & 6.00 & 0.00 \\
\hline & & 38 & \multirow{4}{*}{$\begin{array}{l}\text { Reproductive } \\
\text { stage }\end{array}$} & 31.20 & 0.00 \\
\hline & & 39 & & 21.60 & 6.40 \\
\hline & OCT & 40 & & 17.20 & 24.00 \\
\hline & & 41 & & 15.60 & 13.20 \\
\hline & & 42 & \multirow{6}{*}{$\begin{array}{l}\text { Ripening } \\
\text { stage }\end{array}$} & 1.50 & 8.80 \\
\hline & & 43 & & 22.00 & 17.20 \\
\hline & & 44 & & 5.60 & 12.00 \\
\hline & NOV & 45 & & 8.40 & 14.40 \\
\hline & & 46 & & 0.40 & 15.20 \\
\hline & & 47 & & 0.89 & 9.60 \\
\hline Mean & & & & 10.01 & 7.81 \\
\hline S.D \pm & & & & 8.24 & 8.04 \\
\hline
\end{tabular}

SMW-Standard Metreological Week, S.D- Standard Deviation 
Table.3 Trap catches of yellow stem borer in relation to weather parameters during summer and Kharif season 2015

\begin{tabular}{|c|c|c|c|c|c|c|c|c|c|}
\hline Season & Month & SMW & $\begin{array}{l}\text { Stage of the } \\
\text { crop }\end{array}$ & $\begin{array}{l}\text { *Moth } \\
\text { catches } \\
\text { per } \\
\text { week }\end{array}$ & Season & Month & SMW & $\begin{array}{l}\text { Stage of the } \\
\text { crop }\end{array}$ & $\begin{array}{l}\text { *Moth } \\
\text { catches } \\
\text { per week }\end{array}$ \\
\hline \multirow{20}{*}{ Summer } & FEB & 9 & \multirow{7}{*}{$\begin{array}{l}\text { Vegetative } \\
\text { stage }\end{array}$} & 0.20 & \multirow{22}{*}{ Kharif } & & 29 & \multirow{9}{*}{$\begin{array}{c}\text { Vegetative } \\
\text { stage }\end{array}$} & 0.00 \\
\hline & MAR & 10 & & 0.40 & & & 30 & & 0.20 \\
\hline & & 11 & & 15.60 & & & 31 & & 1.00 \\
\hline & & 12 & & 25.60 & & AUG & 32 & & 4.40 \\
\hline & & 13 & & 19.00 & & & 33 & & 6.00 \\
\hline & APR & 14 & & 30.80 & & & 34 & & 9.40 \\
\hline & & 15 & & 39.40 & & & 35 & & 27.40 \\
\hline & & 16 & \multirow{4}{*}{$\begin{array}{l}\text { Reproductive } \\
\text { stage }\end{array}$} & 41.00 & & SEPT & 36 & & 22.80 \\
\hline & & 17 & & 44.40 & & & 37 & & 28.60 \\
\hline & MAY & 18 & & 35.60 & & & 38 & Reproductive & 35.20 \\
\hline & & 19 & & 43.80 & & & 39 & stage & 27.40 \\
\hline & & 20 & \multirow{9}{*}{$\begin{array}{l}\text { Ripening } \\
\text { stage }\end{array}$} & 42.00 & & & 40 & & 16.40 \\
\hline & & 21 & & 27.00 & & OCT & 41 & & 17.60 \\
\hline & & 22 & & 10.80 & & & 42 & \multirow{7}{*}{$\begin{array}{l}\text { Ripening } \\
\text { stage }\end{array}$} & 22.20 \\
\hline & JUN & 23 & & 17.80 & & & 43 & & 16.20 \\
\hline & & 24 & & 11.20 & & & 44 & & 22.20 \\
\hline & & 25 & & 8.20 & & NOV & 45 & & 18.20 \\
\hline & & 26 & & 0.00 & & & 46 & & 5.80 \\
\hline & JULY & 27 & & 0.60 & & & 47 & & 3.20 \\
\hline & & 28 & & 0.00 & & & 48 & & 1.00 \\
\hline Mean & & & & 20.67 & & & & & 14.26 \\
\hline S.D \pm & & & & 16.08 & & & & & 10.86 \\
\hline
\end{tabular}

*Average of five traps,SMW-Standard metreological week, S.D- Standard deviation 
Table.4 Correlation matrix between weather parameters and trap catches of yellow stem borer during Summer and Kharif 2015

\begin{tabular}{|c|c|c|c|c|c|c|c|}
\hline \multirow{3}{*}{ Particulars } & \multirow{3}{*}{$\begin{array}{l}\text { Total } \\
\text { rainfall } \\
(\mathrm{mm}) \\
(\mathrm{X} 1)\end{array}$} & \multicolumn{5}{|c|}{ Weather factors } & \multirow{3}{*}{$\mathrm{R}^{2}$} \\
\hline & & \multicolumn{2}{|c|}{ Temperature $\left({ }^{0} \mathrm{C}\right)$} & \multicolumn{2}{|c|}{$\begin{array}{c}\text { Relative humidity } \\
(\%)\end{array}$} & \multirow{2}{*}{$\begin{array}{l}\text { Sunshine } \\
\text { (hours/day) } \\
\text { (X6) }\end{array}$} & \\
\hline & & $\begin{array}{l}\text { Maximum } \\
\text { (X2) }\end{array}$ & $\begin{array}{l}\text { Minimum } \\
\text { (X3) }\end{array}$ & I & $\begin{array}{l}\text { II } \\
\text { (X5) }\end{array}$ & & \\
\hline & \multicolumn{6}{|c|}{ Summer season } & \\
\hline \multirow{2}{*}{$\begin{array}{l}\text { TRAP } \\
\text { CATCHES }\end{array}$} & -0.096 & $*+0.51$ & $*+0.672$ & $*_{-0.562}$ & -0.229 & $*+0.411$ & 0.76 \\
\hline & \multicolumn{6}{|c|}{ Kharif season } & \\
\hline $\begin{array}{l}\text { TRAP } \\
\text { CATCHES }\end{array}$ & $-0.379 *$ & $*+0.477$ & 0.364 & -0.376 & -0.307 & $*_{-} 0.55$ & 0.45 \\
\hline
\end{tabular}

$\mathrm{N}=20$; * significant at $\mathrm{p}=0.05 ;$ Table $\mathrm{r}$ value at $\mathrm{p}=0.05$ is 0.378

Figure.1 Seasonal incidence of yellow stem borer during Summer 2015

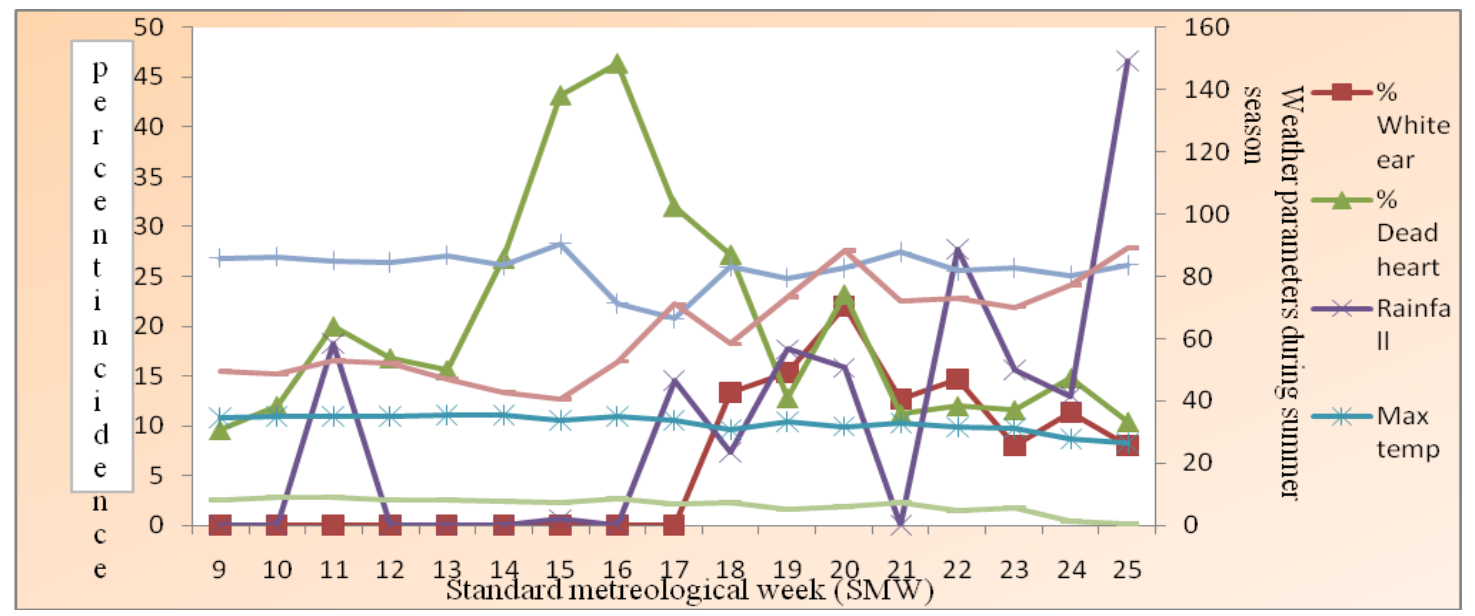

Figure.2 Seasonal incidence of yellow stem borer duringKharif 2015

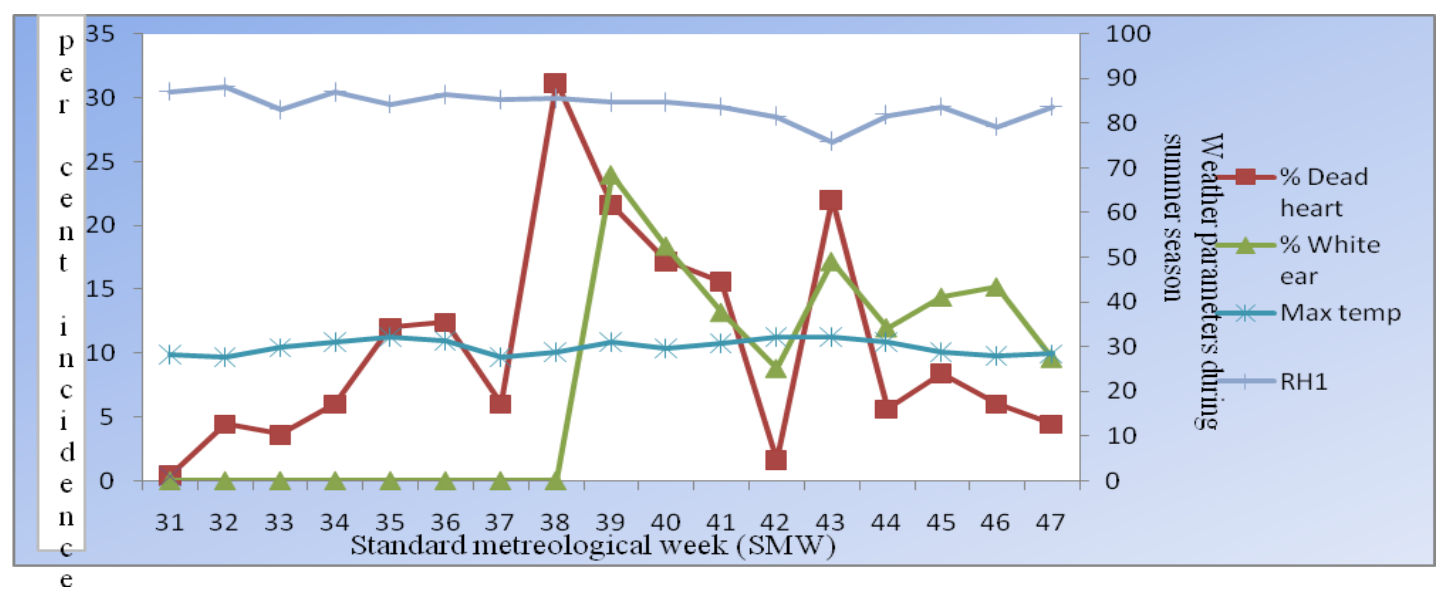


Figure.3 Monitoring of trap catches of yellow stem borer using sex pheromone during Summer 2015

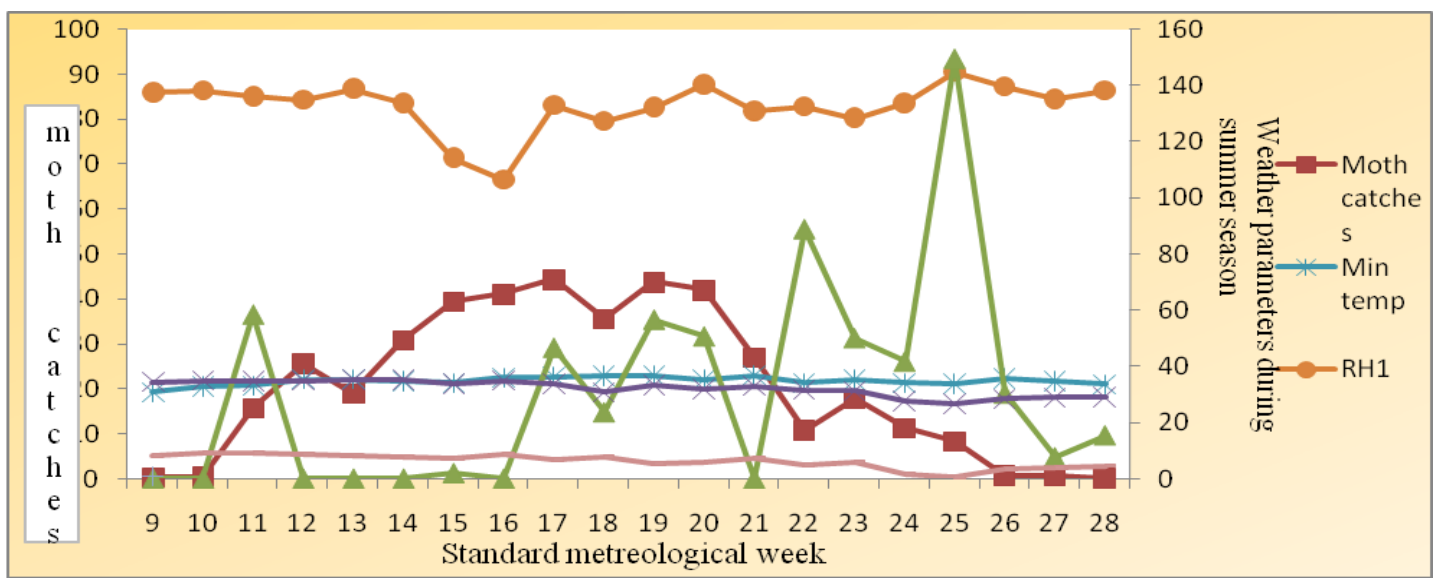

Figure.4 Monitoring of trap catches of yellow stem borer using sex pheromone during Kharif 2015

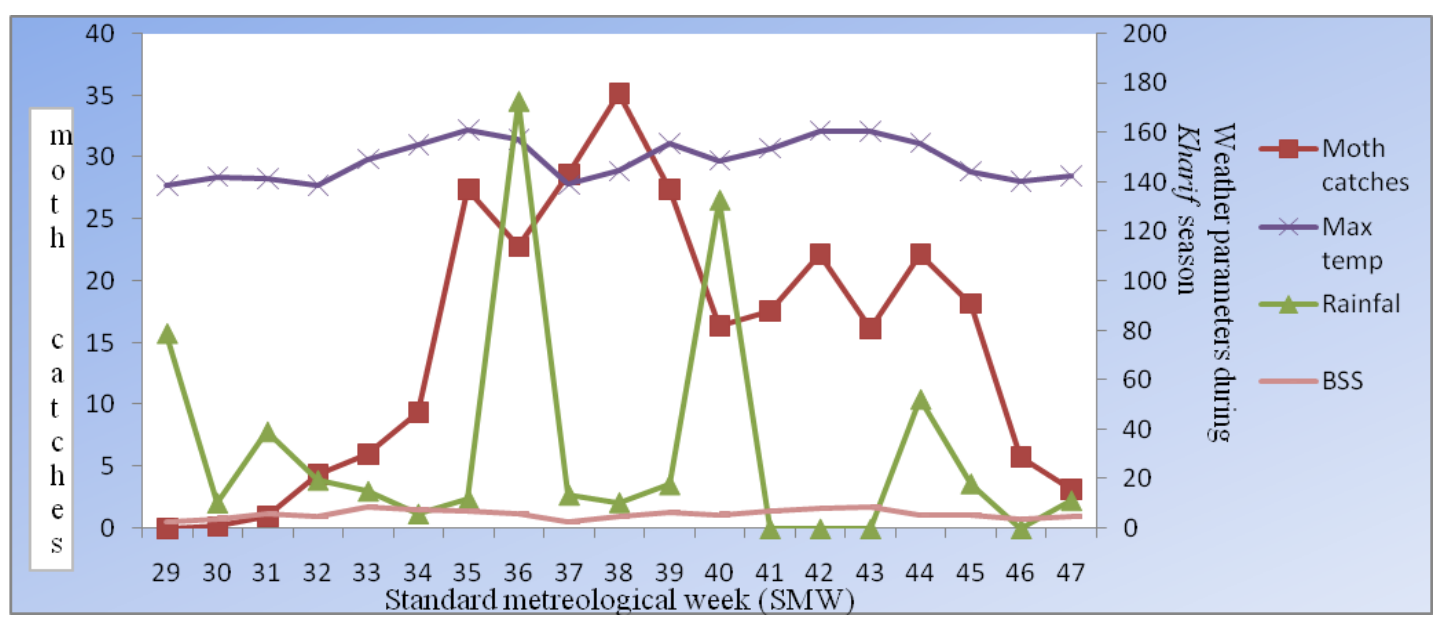

Thorough understanding of the insect ecology forms a basis for effective pest management and conservation of natural enemies. A major part of insect ecology can be understood if the factors influencing its population are thoroughly investigated. Among these factors, weather parameters are the important and there is a need to understand these influences (Mathur et al., 1999). Keeping this in view, the investigation was carried out to study the seasonal incidence of yellow stem borer on paddy during summer and Kharif season of 2015.
The present findings indicated that the incidence of yellow stem borer was high with 46.40 per cent dead heart during $16^{\text {th }}$ standard metrological week i.e., third week of April during summer season, while it was 31.20 per cent dead heart during $38^{\text {th }}$ standard week i.e., second week of September during Kharif season (Figure 1 and 2).

The present findings are similar to the findings of Adiroubane and Raja (2006) who reported that high yellow stem borer incidence was observed during months of 
March (Rabi, 2005), August- September (Kharif, 2006) and October- November (Rabi, 2006). Further Ishhaque and Rahman (1983), Kumar and Sudhakar (2001) reported that the yellow stem borer incidence was higher during the months of March and April during summer. Further Nirala et al., (2015) reported that the maximum per cent incidence of dead heart observed during 36 SMW and 37 SMW in month of September with 18.48 and 10.25 per cent/hill, respectively. Later Kumar and sudhakar (2001), Hugar and Hosamani (2010), Chavan et al., (2013), Kakde and Patel (2014), reported yellow stem borer gain peak infestation during the months of September and October.

The present path analysis revealed that maximum temperature $(\mathrm{r}=0.489)$ had significant positive correlation on YSB incidence while morning relative humidity $(\mathrm{r}$ $=0.377$ ) had non-significant negative influence. On the other hand remaining factors had non significant correlation on the incidence of yellow stem borer during summer. During Kharif, maximum temperature had significant positive correlation $(\mathrm{r}=0.488)$ while morning relative humidity $(r=0.557)$ had significant negative correlation, where as remaining weather parameters had no significant correlation on yellow stem borer incidence.

The present results are in agreement with the findings of Adibourne and Raja (2006), who reported that maximum temperature had negative correlation except he reported that showing positive correlation for minimum temperature and relative humidity. Further Jastin and Preetha (2013) from Tamilnadu during Kharif season reported that both maximum temperature and morning relative humidity had a major role in incidence of yellow stem borer.

The present study indicated that the population of yellow stem borer reached peak of 44.40 moths per week during $17^{\text {th }}$ standard meteorological week i.e., $4^{\text {th }}$ week of April, while it was 35.20 moths per week during 38thstandard meteorological week i.e., $3^{\text {rd }}$ week of September during Kharif season. The present findings are in agreement with Ishhaque and Rahman (1983), who reported that Peak catches of yellow stem borer moths were recorded during April - May in summer. Further Hall et al., (1992) reported that, the catching of moth in trap was commenced as early as $2^{\text {nd }}$ week of august with its peak during September month.

The present path analysis revealed that maximum temperature $(\mathrm{r}=0.51)$, minimum temperature (0.67) and sunshine hours $(\mathrm{r}=$ 0.411 ) had significant positive correlation on YSB moth catches while morning relative humidity $(r=0.562)$ had significant negative influence. On the other hand remaining factors viz., total rainfall and afternoon relative humidity had negative non significant correlation on the moth catches during summer. During Kharif, maximum temperature had significant positive correlation $(r=0.477)$ while sunshine hours $(r$ $=0.55$ ) had significant negative correlation, where as remaining weather parameters viz., total rainfall, morning relative humidity, afternoon relative humidity had negative non significant correlation on moth catches. Further Somashekara and Javaregowda (2015) reported that there was a positive correlation between yellow stem borer catches with the maximum temperature $(r=0.19)$ and negative correlation with the total rainfall $(\mathrm{r}=-$ $0.379)$ and afternoon relative humidity $(\mathrm{r}=-$ 0.59 ) and contrary with the minimum temperature, morning relative humidity.

\section{References}

Adiroubane, D., and Raja, K., 2006, Influence of Weather Parameters on the Occurrence of Rice Yellow Stem Borer, Scirpophaga incertulus (Walker).J. of 
Rice Res., 3(1): 6-7.

Chavan, S. M., Patel, K. G., and Arve, S. S., 2013, Seasonal incidence of rice yellow stem borer, Scirpophaga incertulas (walker) in relation to crop growth stages under south Gujarat condition. An Int.e-J.,2(232): 2277-9663.

Hall, D. R., Beevor, P. S., Cork, A., Tjones, O., and Howse P. E., 1994, Use of pheromones in control of insect pests of rice. In New Frontiers in Rice Res., proceedings of Silver Jubilee Symposium of Directorate of Rice Res., Hyderabad, Pp. 226-234.

Hugar, S. V., Hosamani, V., Pradeep, S., and Hanumanthaswamy, B. C. 2009, Evaluation of New Chemical Molecules for the Management of Scirpophaga incertulas Walker, in Aerobic rice. Int. J. of Pl. Prot., 2(2): 205-208.

Ishhaque, N. M. M., and Rahman, A., 1983, Seasonal abundance of rice stem borer, Tryporyza incertulas (wlk.) in Assam. Pesticides, 17(1): 25-27.

Ishhaque, N. M. M., and Rahman, A., 1983, Seasonal abundance of rice stem borer, Tryporyza incertulas (wlk.) in Assam. Pesticides, 17(1): 25-27.

Kakde, A. M., and Patel, K. G., 2014, Seasonal Incidence of Rice Yellow Stem (Scirpophaga incertulas Wlk.) in Relation to Conventional and Sri Methods of Planting and Its Correlation with Weather Parameters. J. of Agric. and Veterinary Sci., 7 (6): 5-10.

Krishnaiah, K., and Varma, N. R. G., 2011,
Changing insect pest scenario in the rice ecosystem - A national perspective. Rice Knowledge Management, pp. 128.

Kumar, A. D. V. S. L. P. A., and Sudhakar, T. R., 2001, Incidence of the yellow stem borer, Scirpophaga incertulas (Walker), on rice in relation to weather parameters. Pest Management and Econ. Zool., 9(2): 161-164.

Mathur, K. C., Reddy, P. R., Rajamali, S., and Moorthy, B. T. S., 1999, Integrated pest management of rice to improve productivity and sustainability. Oryza, 36(3): 195-207.

Nirala Y. S., Chandrakar, G., Ghirtlahre S. K., and Sahu, C., 2015, Seasonal incidence of yellow stem borer, Scirpophaga incertulas walker in midland sri and normal transplanted rice ecosystem. An int. Quarterly J. Environ. Sci., 9 (1): 445-448.

Patel, H. R., and Shekh, A. M. 2006. Pest epidemics and role of meteorological services - an overview. $J$. Agrometeorology, 8 (1): 104-113.

Pathak, M. D., and Khan, Z., R. 1994, Insect pests of rice. International Rice Research institute, Los Banos, Philippines.

Somashekara, H., and Javaregowda., 2015, Population build up of paddy yellow stem borer (Scirpophaga incertulus Walker) in relation to different weather parameters. Karnataka J. Agric. Sci., 28(2): 282-283.

\section{How to cite this article:}

Pallavi, D., Sharanabasappa and Megaladevi, P. 2018. Seasonal Fluctuation of Yellow Stem Borer Scirpophaga incertulas (walker) on Paddy and Its Relationship between Trap Catches with Weather Parameters. Int.J.Curr.Microbiol.App.Sci. 7(09): 3575-3584.

doi: https://doi.org/10.20546/ijcmas.2018.709.443 